\title{
OBJECTIVES OF THE QUALITY CONTROL SYSTEM FOR CONSTRUCTION AND INSTALLATION OPERATIONS IN VIETNAM
}

\author{
Thai Nguyen ${ }^{1}$, Antonina Yudina ${ }^{2}$ \\ 1,2 Saint Petersburg State University of Architecture and Civil Engineering \\ Vtoraja Krasnoarmejskaja st., 4, St. Petersburg, Russia \\ ${ }^{2}$ Corresponding author: yudinaantonina2017@mail.ru
}

\begin{abstract}
Introduction: The quality control system for construction and installation operations pursues six objectives: completion on time; completion on budget; compliance with the design documents, codes, and standards; safe operations; improvement of skills and experience; environment protection. Purpose of the study: To evaluate reliability of the objectives, correlation between them, and ranking of their priorities within the quality control system for construction and installation operations in Vietnam. Methods: The objectives were evaluated by means of a questionnaire survey conducted in Vietnam, using a five-level scale, based on the reliability coefficient $\alpha$, correlation coefficient $r$ and mean value $M$. The sample size was 184. Results: According to the results of the questionnaire survey conducted in Vietnam, homogeneity and correlation between the following objectives was observed: compliance with the design documents, codes, and standards; safe operations; improvement of skills and experience; completion on time; completion on budget; environment protection. The objectives were ranked between two groups of respondents by their experience and roles based on the sample size.
\end{abstract}

\section{Keywords \\ Quality control, construction, system, construction and installation operations, Vietnam.}

\section{Introduction}

To consider factors affecting quality of construction operations (Nguyen, Yudina, 2017), a quality control system shall be developed as the contractor influences quality but does not participate in quality control system development (Low, Peh, 1996). As for Vietnam, such quality control system is especially important (Yudina, Nguyen, 2018). Quality control is a part of quality management focused on fulfilling quality requirements (ISO 9000:2015). Quality control primarily deals with issues relating to conformance to the plans and specifications (Low, Ong, 2014). In the field of construction, quality control involves quality assurance with regard to construction of buildings and structures by building contractors with efficient control at all stages of construction product manufacturing (Badyin et al., 2011). In other words, quality requirements represent

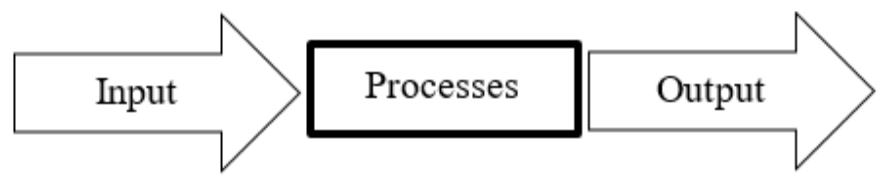

Figure 1. Main components of a system. the objective of the quality control system, which is quality control over construction and installation operations. Any system includes three main components: input, process, and output (Figure 1).

Output of the quality control system for construction and installation operations is desired results, or system objectives. Those objectives can include the following: consumer-oriented objective, employee-oriented objective, society-oriented objective, and key operating results (Maslov, Vylgina, 2006). In particular, objectives of the quality control system in construction can include the following: completion on time $\left(G_{1}\right)$; completion on budget $\left(G_{2}\right)$; compliance with the design documents, codes, and standards $\left(G_{3}\right)$; safe operations $\left(G_{4}\right)$; improvement of skills and experience $\left(G_{5}\right)$; environment protection $\left(G_{6}\right)$ (Arditi, Gunaydin, 1997; Cooke, Williams, 2009; Rogalska et al., 2007).

\section{Methods and materials}

Polling in the form of a questionnaire was used. The questionnaire prepared by one of the authors of the paper was distributed to employees in the construction industry in Vietnam. Six objectives of the quality control system 
were graded on a five-level scale $(1-$ not important, 2 - less important, 3 - important, 4 - very important, 5 most important). As a result, 184 responds were obtained.

\section{Results and discussion}

\section{Evaluating reliability of the objectives}

Reliability of the objectives $\left(G_{1}, G_{2}, G_{3}, G_{4}, G_{5}, G_{6}\right)$ was evaluated using the Cronbach's alpha coefficient ( $\alpha$ ) as the coefficient $\alpha$ represents a measure of internal consistency, or homogeneity of a measuring scale (Cronbach, 1951; Nasledov, 2013):

$$
\alpha=\frac{k \cdot r}{1+(k-1) \cdot r}
$$

where $k$ is the number of scale points, $r$ is a mean coefficient of correlation between each item and the sum of other items. The value of $\alpha>0.9=$ excellent; $\alpha>0.8=$ good; $\alpha>0.7=$ acceptable; $\alpha>0.6=$ questionable; $\alpha>$ $0.5=$ poor; $\alpha<0.5=$ unacceptable. The obtained value of $\alpha=0.860$ (Table 1) indicates internal consistency, or homogeneity, of the objectives.

Table 1. Cronbach's alpha coefficient.

\begin{tabular}{|c|c|c|c|c|}
\hline No. & $\begin{array}{c}\text { Objec- } \\
\text { tives }\end{array}$ & $\begin{array}{c}\text { Adjusted correla- } \\
\text { tion between the } \\
\text { item and the total } \\
\text { score }\end{array}$ & $\begin{array}{l}\text { Cronbach's } \\
\text { alpha with } \\
\text { the item } \\
\text { excluded }\end{array}$ & $\begin{array}{c}\text { Cronbach's } \\
\text { alpha }\end{array}$ \\
\hline 1 & $G_{1}$ & 0.686 & 0.830 & \multirow{6}{*}{0.860} \\
\hline 2 & $G_{2}$ & 0.685 & 0.830 & \\
\hline 3 & $G_{3}$ & 0.490 & 0.862 & \\
\hline 4 & $G_{4}$ & 0.723 & 0.823 & \\
\hline 5 & $G_{5}$ & 0.697 & 0.828 & \\
\hline 6 & $G_{6}$ & 0.631 & 0.840 & \\
\hline
\end{tabular}

\section{Correlation between the objectives}

The correlation between the objectives $\left(G_{1}, G_{2}, G_{3}\right.$, $G_{4}, G_{5}, G_{6}$ ) was measured using the Pearson correlation coefficient $r_{x y}$ :

$r_{x y}=\frac{\sum\left(X_{i}-\bar{X}\right)\left(Y_{i}-\bar{Y}\right)}{\sqrt{\sum\left(X_{i}-\bar{X}\right)^{2}\left(Y_{i}-\bar{Y}\right)^{2}}}$

Here $X_{i}, Y_{i}, \bar{X}, \bar{Y}$ are variables' values and their mean.

If $r_{x y} \rightarrow 1, X$ and $Y$ have a positive linear correlation; if $r_{x y} \rightarrow-1$, then $X$ and $Y$ have a negative linear correlation; if $r_{x y}=0$, then $X$ and $Y$ do not correlate.

The correlation level $\left|r_{x y}\right|=0.3-0.4$ indicates weak correlation, $\left|r_{x y}\right|=0.5-0.75-$ good correlation, $\left|r_{x y}\right|=$ 0.8-0.95 - very good correlation, $\left|r_{x y}\right|=1$ shows the deterministic nature (Efimov, 2003).

Table 2. Correlation between the objectives.

\begin{tabular}{|c|c|c|c|c|c|c|}
\hline $\begin{array}{c}\text { Objec- } \\
\text { tives }\end{array}$ & $G_{1}$ & $G_{2}$ & $G_{3}$ & $G_{4}$ & $G_{5}$ & $G_{6}$ \\
\hline$G_{1}$ & 1 & 0.752 & 0.357 & 0.505 & 0.476 & 0.510 \\
\hline$G_{2}$ & 0.752 & 1 & 0.360 & 0.556 & 0.537 & 0.404 \\
\hline$G_{3}$ & 0.357 & 0.360 & 1 & 0.462 & 0.429 & 0.371 \\
\hline$G_{4}$ & 0.505 & 0.556 & 0.462 & 1 & 0.654 & 0.595 \\
\hline$G_{5}$ & 0.476 & 0.537 & 0.429 & 0.654 & 1 & 0.587 \\
\hline$G_{6}$ & 0.510 & 0.404 & 0.371 & 0.595 & 0.587 & 1 \\
\hline
\end{tabular}

The "completion on time" $\left(G_{1}\right)$ and "completion on budget" $\left(G_{2}\right)$ objectives have a strong correlation with the correlation coefficient $|r|=0.752$ (Table 2 ), demonstrating that completion on time will allow staying on budget. And vice versa, if the "completion on budget" $\left(G_{2}\right)$ objective is achieved, then the "completion on time" $\left(G_{1}\right)$ objective will be achieved as well.

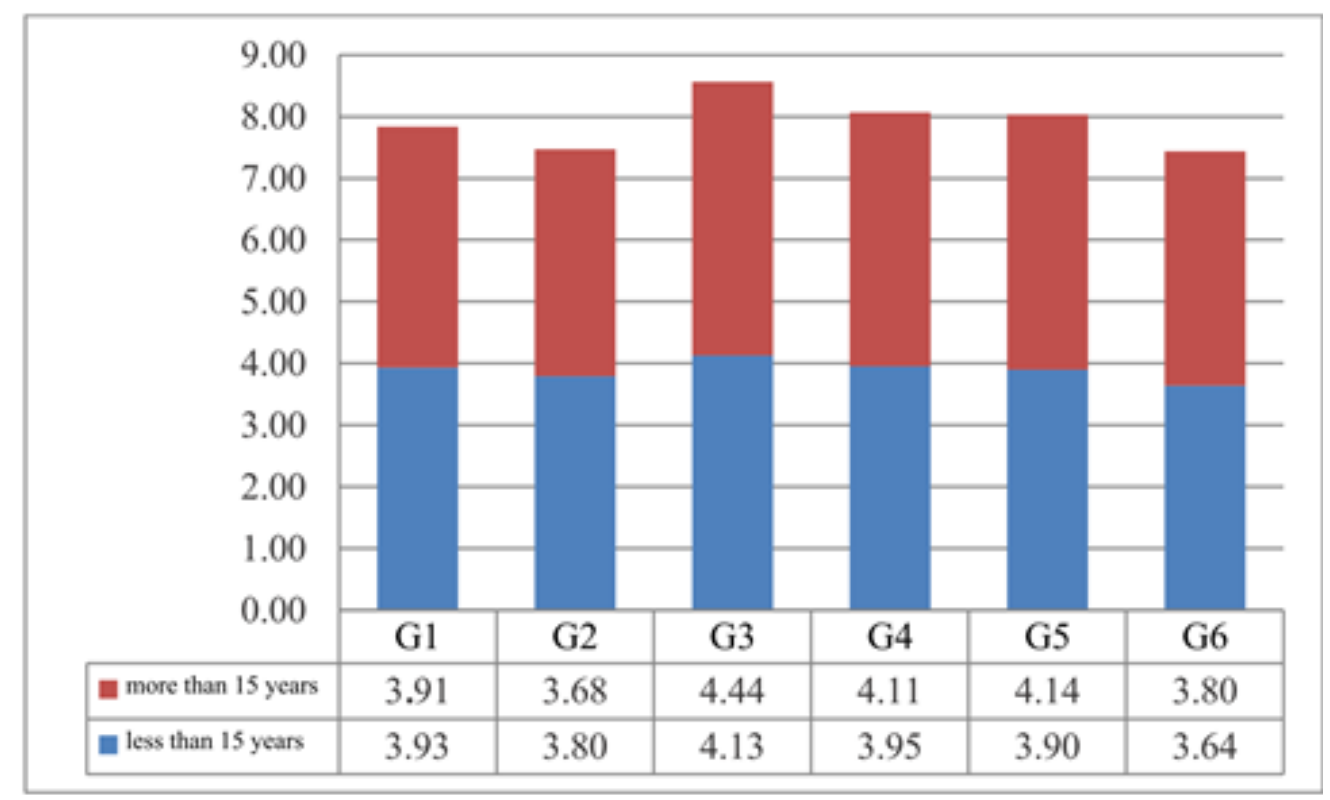

Figure 2. Ranking of the quality control system objectives based on experience of the respondents. 


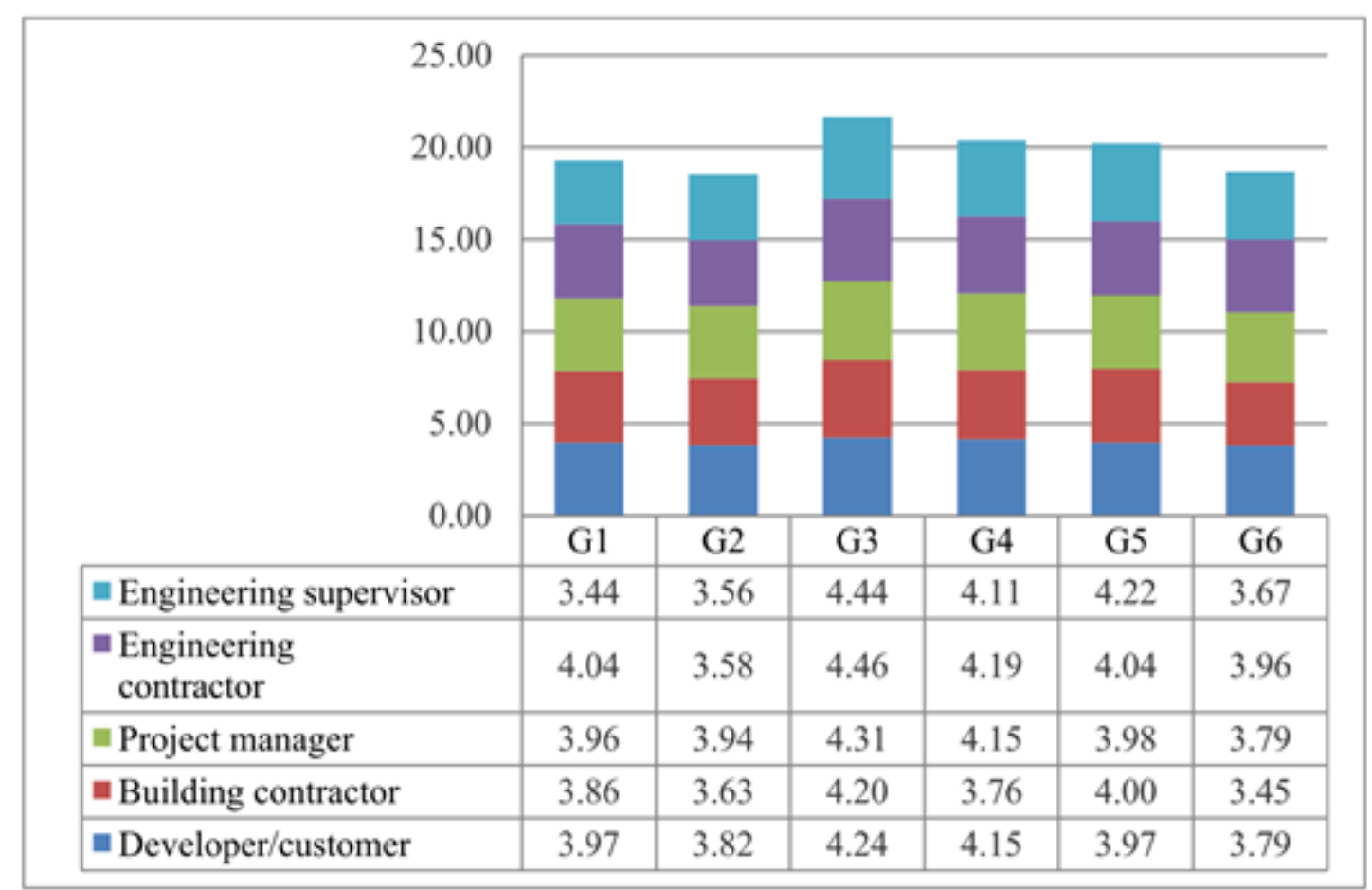

Figure 3. Ranking of the quality control system objectives based on roles of the respondents.

The "compliance with the design documents, codes, and standards" $\left(G_{3}\right)$ objective closely correlates with the "safe operations" $\left(G_{4}\right)$ objective $(|r|=0.462)$ and the "improvement of skills and experience" $\left(G_{5}\right)$ objective $(|r|=0.429)$ (Table 2). This correlation shows that if the "compliance with the design documents, codes, and standards" $\left(G_{3}\right)$ objective is achieved, employees will work safely and improve their skills and experience. At the same time, safe operations as well as improved skills and experience will ensure better compliance with the design documents, codes, and standards.

The "safe operations" $\left(G_{4}\right)$ objective correlates with the "improvement of skills and experience" (G5) objective, with the correlation coefficient $|r|=0.654$ (Table 2). According to this dependence, if employees work safely, their skills and experience will improve, i.e. qualified personnel will work under safer conditions.

The "environment protection" $\left(G_{6}\right)$ objective correlates with the "safe operations" $\left(G_{4}\right)$ objective $(|r|=0.595)$ and the "improvement of skills and experience" $\left(G_{5}\right)$ objective $(|r|=0.587)$ (Table 2). According to this dependence, the "environment protection" $\left(G_{6}\right)$ objective can be achieved only when employees work safely and improve their skills.

\section{Ranking of the objectives}

The objectives $\left(G_{1}, G_{2}, G_{3}, G_{4}, G_{5}, G_{6}\right)$ were evaluated by five levels, their mean value was calculated as follows:

$$
M=\frac{\sum_{i=1}^{N} w_{i}}{N}
$$

where $M$ is the mean value; $w_{i}$ is the evaluation level ( $w$ $=1-5), N$ is the sample size $(N=184)$.
The objectives were ranked using three criteria: experience of the respondents, roles of the respondents, and total score. $52.2 \%$ respondents $(n=96)$ had more than 15 years of experience, and $47.8 \%(n=88)$ had less than 15 years of experience. Both groups agree that "compliance with the design documents, codes, and standards" $\left(G_{3}\right)$ is the primary objective of the quality control system for construction and installation operations. In the meantime, such quality control system has a minor effect on the "completion on budget" $\left(G_{2}\right)$ and "environment protection" $\left(G_{6}\right)$ objectives (Figure 2 ).

The respondents had the following roles: building contractor $(27.72 \%)$, project manager $(26.09 \%)$, developer/ customer $(18.48 \%)$, engineering contractor $(14.13 \%)$ and engineering supervisor (4.89\%) (Table 3 ).

Table 3. Roles of respondents.

\begin{tabular}{|c|l|l|l|l|}
\hline No. & Role & $\begin{array}{l}\text { Number } \\
\text { of respon- } \\
\text { dents, } \mathrm{n}\end{array}$ & $\begin{array}{l}\text { Per cent, } \\
\%\end{array}$ & $\begin{array}{l}\text { Cumulative } \\
\%\end{array}$ \\
\hline 1 & $\begin{array}{l}\text { Building con- } \\
\text { tractor }\end{array}$ & 51 & 27.72 & 27.72 \\
\hline 2 & $\begin{array}{l}\text { Project man- } \\
\text { ager }\end{array}$ & 48 & 26.09 & 53.80 \\
\hline 3 & $\begin{array}{l}\text { Developer/cus- } \\
\text { tomer }\end{array}$ & 34 & 18.48 & 72.28 \\
\hline 4 & $\begin{array}{l}\text { Engineering } \\
\text { contractor }\end{array}$ & 26 & 14.13 & 86.41 \\
\hline 5 & $\begin{array}{l}\text { Engineering } \\
\text { supervisor }\end{array}$ & 9 & 4.89 & 91.30 \\
\hline 6 & Other & 16 & 8.70 & 100.0 \\
\hline & Total $(N)$ & 184 & 100.0 & \\
\hline
\end{tabular}




\section{Architecture and Engineering Volume 4 Issue 2}

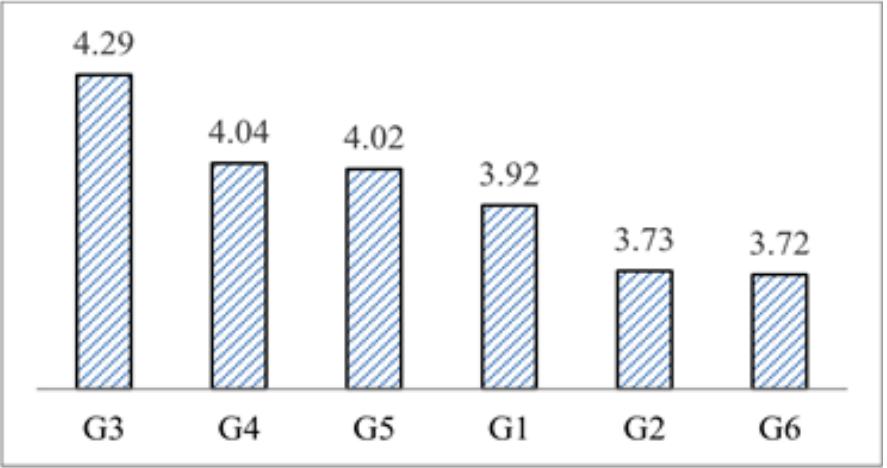

Figure 4. Ranking of the objectives in the quality control system for construction and installation operations based on the data of the questionnaire survey conducted in Vietnam.

The objectives were evaluated in the entire sample size $(N=184)$. The hierarchy of the quality control system objectives includes: compliance with the design documents, codes, and standards $\left(G_{3}\right)$; safe operations $\left(G_{4}\right)$; improvement of skills and experience $\left(G_{5}\right)$; completion on time $\left(G_{1}\right)$; completion on budget $\left(G_{2}\right)$; environment protection $\left(G_{6}\right)$ (Figure 4).

\section{Conclusions}

Rankings of the objectives by experience, by roles and in the entire sample size give similar results. Assurance of compliance with the design documents, codes, and standards represents the primary objective of the quality control system for construction and installation operations in Vietnam. This objective correlates with the "safe operations" $\left(G_{4}\right)$ and the "improvement of skills and experience" $\left(G_{5}\right)$ objectives. Therefore, to achieve it, it is necessary to provide safe labor conditions and have plans for skills improvement in place. This objective can meet the requirements of consumers (Nguyen, Yudina, 2017) and employees in accordance with the quality control mechanism in the construction industry in Vietnam (Yudina, Nguyen, 2018). Its achievement provides a basis for achievement of quality in construction and installation operations at a construction facility in Vietnam. 


\section{References}

Arditi, D., Gunaydin, H. M. (1997). Total quality management in the construction process. International Journal of Project Management, 15 (4), pp. 235-243. DOI: 10.1016/S0263-7863(96)00076-2.

Badyin, G. M., Verstov, V. V., Likhachev, V. D., Yudina A. F. (2011). Construction operations. Basic terms and definitions. Saint Petersburg: Saint Petersburg State University of Architecture and Civil Engineering.

Cooke, B., Williams, P. (2009). Construction Planning, Programming, and Control. 3rd edition. Oxford: Wiley-Blackwell.

Cronbach, L. J. (1951). Coefficient alpha and the internal structure of tests. Psychometrika, 16 (3), pp. $297-334$.

Efimov, V. V. (2003). Statistical methods in quality management. Ulyanovsk: Ulyanovsk State Technical University.

ISO 9000:2015. Quality management systems - Fundamentals and vocabulary.

Low, S. P., Ong, J. (2014). Project Quality Management. Critical Success Factors for Buildings. Singapore: Springer Science+Business Media Singapore.

Low, S. P., Peh, K.-W. (1996). A framework for implementing TQM in construction. The TQM Magazine, 8 (5), pp. 39-46. DOI: 10.1108/09544789610146033.

Maslov, D. V., Vylgina, Yu. V. (2006). Modern management tools. EFQM improvement model: study guide. Ivanovo: Ivanovo State Power Engineering University.

Nasledov, A. (2013). IBM SPSS Statistics 20 and AMOS: professional statistical analysis of data. Saint Petersburg: Piter.

Nguyen, T. H., Yudina, A. F. (2017). Analysis of factors affecting construction quality. In: Proceedings of 70th All-Russian Scientific and Practical Conference of Students, PhD Students and Young Scientists "Challenging Issues of Modern Construction". Saint Petersburg: Saint Petersburg State University of Architecture and Civil Engineering, pp. 74-80.

Rogalska, M., Heyduzki, Z., Egorov, A. N. (2007). Analysis of factors affecting efficiency of building objects. Bulletin of Civil Engineers, 1 (10), pp. 59-64.

Yudina, A. F., Nguyen, T. H. (2018). Quality control mechanisms in the construction industry of Vietnam. Bulletin of Civil Engineers, 1 (66), pp. 88-96. DOI: 10.23968/1999-5571-2018-15-1-88-96. 


\title{
ЦЕЛИ СИСТЕМЫ КОНТРОЛЯ КАЧЕСТВА СТРОИТЕЛЬНО-МОНТАЖНЫХ РАБОТ В УСЛОВИЯХ ВЬЕТНАМА
}

\author{
Тхай Хиеп Нгуен ${ }^{1}$, Антонина Федоровна Юдина² \\ 1,2 Санкт-Петербургский государственный архитектурно-строительный университет \\ 2-ая Красноармейская ул., 4, г. Санкт-Петербург, Россия
}

${ }^{2}$ Автор, ответственный за переписку: yudinaantonina2017@mail.ru

\begin{abstract}
Аннотация
Введение: Система контроля качества строительно-монтажных работ (СМР) состоит из 6 целей: завершение в срок, завершение в рамках бюджета, соответствие проектным документам, кодексу, стандартам, работа в безопасных условиях, совершенствование своих навыков и опыта, а также охрана окружающей среды. Цель исследования: оценить надежность целей, корреляцию между целями и ранжирование приоритетов этих целей в системе контроля качества СМР в условиях Вьетнама. Методы: Цели оценивались по пятиуровневой шкале с помощью анкетирования, проводимого во Вьетнаме, с размером выборки 184, на основе коэффициента надежности $\alpha$, коэффициента корреляции $r$ и среднее значение М. Результаты: На основании результатов проведенного анкетирования во Вьетнаме, показана однородность и корреляция между следующими целями: соответствие проектным документам, кодексу, стандартам, работа в безопасных условиях, усовершенствование своих навыков и опыта, завершение в срок, завершение в рамках бюджета, охрана окружающей среды. Цели ранжировались между двумя группами участников опроса по опыту и роли на основе размера выборки.
\end{abstract}

\section{Ключевые слова}

Контроль качества, строительство, строительно-монтажные работы, Вьетнам. 